\title{
Peran Guru Dalam Meningkatkan Keterampilan Membaca Pada Siswa Kelas II SD
}

\author{
Kurnia Is Utami Dewi
}

SDN Tlogorejo 3

kurniadewi1123@gmail.com

\section{Article History}

received 3/12/2020

\begin{abstract}
The duties and responsibilities of a teacher include creating an atmosphere or climate for the learning process that can motivate students to always study well and enthusiastically. The teacher's role is as an educator, teacher, mentor, director, trainer, assessor, and evaluator of students. Reading is a language skill that has a very important role in life. Cultured and educated humans make reading a necessity in communication. By reading students will easily get knowledge and insight from anywhere. Based on the above, it can be concluded that without good reading skills, students will not be able to understand the learning process and the material being taught. Therefore, the teacher's role is needed in improving reading skills in second grade elementary school students.
\end{abstract}

Keywords: the role of the teacher, reading

\begin{abstract}
Abstrak
Tugas dan tanggung jawab seorang guru diantaranya adalah menciptakan suasana atau iklim proses pembelajaran yang dapat memotivasi siswa untuk senantiasa belajar dengan baik dan semangat. Peran guru adalah sebagai pendidik, pengajar, pembimbing, pengarah, pelatih, penilai, dan pengevaluasi dari peserta didik. Membaca merupakan suatu keterampilan berbahasa yang sangat penting peranannya dalam kehidupan. Manusia yang berbudaya dan berpendidikan menjadikan membaca menjadi suatu kebutuhan dalam berkomunikasi. Dengan membaca siswa akan mudah mendapatkan pengetahuan dan wawasan dari mana saja. Berdasarkan hal tersebut di atas dapat disimpulkan bahwa tanpa adanya kemampuan membaca yang baik, maka siswa tidak akan dapat memahami proses pembelajaran dan materi yang diajarkan. Oleh karena itu peran guru sangat dibutuhkan dalam meningkatkan keterampilan membaca pada siswa kelas II SD.
\end{abstract}

Kata kunci: peran guru, membaca

Social, Humanities, and Education Studies (SHEs): Conference Series https://jurnal.uns.ac.id/shes

p-ISSN 2620-9284

e-ISSN 2620-9292 


\section{PENDAHULUAN}

Mata pelajaran Bahasa Indonesia diberikan di semua jenjang pendidikan formal. Dengan demikian diperlukan standar kompetensi mata pelajaran Bahasa Indonesia yang memadai dan efektif sebagai alat berkomunikasi, berinteraksi sosial, media pengembangan ilmu dan alat pemersatu bangsa. Mata pelajaran Bahasa Indonesia di SD terdiri dari aspek mendengarkan, berbicara, membaca dan menulis. Salah satu aspek yang akan dibahas pada artikel ini adalah membaca. Dengan membaca seseorang mendapat pengetahuan dan informasi dari berbagai penjuru dunia. Membaca menjadi suatu kaharusan yang dilakukan oleh pribadi yang menanamkan dirinya sebagai intelektual. Untuk itulah diperlukan peran dari guru dalam meningkatkan keterampilan membaca terutama di kelas II SD yang merupakan kelas rendah dimana keterampilan membaca ini belum sepenuhnya dikuasai oleh semua siswa. Oleh karena itu, siswa masih membutuhkan bimbingan dan pengajaran dari guru. Sebagaimana prinsip yang di kemukakan oleh bapak pendidikan Indonesia yaitu Ki Hajar Dewantara yang berbunyi "ing ngarso sung tulodho, ing madyo mangun karso, tut wuri handayani." Artinya seorang guru bila di depan memberikan suri teladan (contoh), di tengah memberikan prakarsa dan di belakang memberikan dorongan atau motivasi. Dimana seorang guru mempunyai tugas utama yaitu mendidik, membimbing, melatih dan mengembangkan kurikulum (perangkat kurikulum).

Salah satu faktor penting yang harus dilakukan pemerintah dalam meningkatkan kemajuan suatu bangsa adalah dengan melahirkan sumber daya manusia (SDM) yang bermutu juga bermartabat. Bangsa yang maju terlahir dari sumber daya manusia (SDM) yang memiliki kualitas baik. Untuk melahirkan SDM yang bermutu bukanlah suatu hal yang mudah dilakukan dan hal tersebut menjadi salah satu tantangan dalam perangkat pendidikan. Pendidikan dianggap sebagai suatu hal yang paling penting dalam suatu negara, karena maju dan tertinggalnya suatu negara tergantung pada kondisi pendidikannya. Sehingga pendidikan merupakan gerbang utama dalam melahirkan sumber daya manusia (SDM) yang berkualitas bagi kemajuan suatu bangsa dan negara. Dalam UU No. 20/2003 tentang sistem Pendidikan Nasional dalam pasal 1 menunjukkan bahwa pengertian pendidikan adalah suatu usaha secara sadar dan terencana yang bertujuan untuk mewujudkan suasana belajar dan proses pembelajaran supaya anak didik secara aktif dapat mengembangkan potensi dalam dirinya sehingga memperoleh kekuatan baik dalam hal spiritual agama, mengendalikan diri, kepribadian, kecerdasan, akhlak yang mulia, maupun keterampilan yang diperlukan oleh dirinya, masyarakat, bangsa dan negara. Pendidikan mengandung pembinaan kepribadian, pengembangan kemampuan, atau potensi yang perlu dikembangkan. Peningkatan kemampuan dari tidak tau menjadi tau, serta tujuan ke arah mana peserta didik dapat mengaktualisasikan dirinya seoptimal mungkin. Pendidikan merupakan sebuah wadah untuk membentuk kualitas bangsa. Salah satu upaya yang bisa dilakukan pemerintah untuk memperbaiki penerus bangsa adalah dengan memperbaiki kualitas pendidikan yang ada di negara itu sendiri. Sekolah sangat berperan penting dalam mengembangkan potensi peserta didik baik berupa kepribadian, kecerdasan, akhlak mulia, serta keterampilan-keterampilan lainnya yang berguna untuk dirinya, masyarakat, bangsa, dan negara. Hal ini jelas tertuang dalam Sistem Pendidikan Nasional No. 20 tahun 2003.

Guru merupakan salah satu orang yang memiliki pengaruh besar terhadap pendidikan di sekolah. Sehingga perlu adanya upaya untuk meningkatkan kualitas guru. Karena jika kualitas diri seorang guru meningkat, tidak menutup kemungkinan bahwa kualitas pendidikan pun akan terus meningkat. Oleh karena itu, program pengembangan dan peningkatan kualitas guru merupakan hal yang penting. Peran guru di sekolah sangat penting agar tercapainya kegiatan belajar mengajar sesuai yang diinginkan. 
Kedudukan guru sebagai komponen pengajaran di samping siswa, kurikulum, metode, alat pelajaran, dan alat evaluasi merupakan penentu keberhasilan. Dengan demikian guru berperan sebagai pembimbing, model, inovator, administrator dan evaluator, terlebih lagi dalam pembelajaran bahasa Indonesia.

\section{Peran Guru}

\section{HASIL DAN PEMBAHASAN}

Jabatan guru adalah suatu profesi yang terhormat dan mulia. Guru mengabdikan diri dan berbakti untuk mencerdaskan kehidupan bangsa dan meningkatkan kualitas manusia seutuhnya, yaitu manusia yang beriman, bertakwa dan berakhlak mulia, serta menguasai IImu Pengetahuan Teknologi, Komunikasi dan Sains (IPTEKS) dalam mewujudkan masyarakat yang berkualitas. Agar menjadi guru yang bermanfaat di lingkungannya berada. Dalam pembelajaran di kelas, upaya guru untuk menciptakan iklim kelas juga menjadi faktor yang sangat penting dalam proses pembelajaran tersebut.

Kemampuan membaca permulaan benar-benar memerlukan perhatian guru, sebab jika dasar membaca itu tidak kuat pada tahap pemula maka tingkat membaca lanjut peserta didik akan mengalami kesulitan untuk dapat memiliki kemampuan membaca yang memadai.

Dalam Undang Undang Nomor 14 tahun 2005 tentang Guru dan Dosen, guru adalah tenaga profesional dengan tugas utama mendidik, mengajar, membimbing, mengarahkan, melatih, menilai, dan mengevaluasi peserta didik pada pendidikan anak usia dini jalur pendidikan formal, pendidikan dasar, dan pendidikan menengah. Tugas pendidik bukanlah hanya sekedar mengajar, pendidik juga bertugas sebagai motivator dan fasilitator dalam proses belajar mengajar sehingga seluruh potensi peserta didik dapat teraktualisasi secara baik dan dinamis. Sedangkan tugas guru sebagai motivator adalah untuk meningkatkan semangat dan gairah belajar yang tinggi. Motivasi tersebut dapat berupa motivasi dari dalam diri sendiri (intrinsik) maupun dari luar (ekstrinsik), yang utama berasal dari gurunya sendiri.

Tugas dan peran guru merupakan sesuatu kesatuan yang utuh. Hanya saja terkadang tugas dan fungsi disejajarkan sebagai penjabaran dari peran menurut Daryanto (Undang-Undang No. 20 Tahun 2003 dan Undang-Undang No. 14 Tahun 2005, 2014:19-21) peran guru adalah sebagai pendidik, pengajar, pembimbing, pengarah, pelatih, penilai, dan pengevaluasi dari peserta didik.

uru Sebagai Pendidik

Guru adalah pendidik, yang menjadi tokoh, panutan dan identifikasi bagi para peserta didik dan lingkungannya. Oleh karena itu guru harus mempunyai standar kualitas pribadi tertentu, yang mencakup tanggungjawab, wibawa, mandiri dan disiplin. Guru harus memahami nilai-nilai, norma moral dan sosial, serta berusaha berperilaku dan berbuat sesuai dengan nilai dan norma tersebut. Guru juga harus bertanggung jawab terhadap tindakannya dalam proses pembelajaran di sekolah. Sebagai pendidik guru harus berani mengambil keputusan secara mandiri berkaitan dengan pembelajaran dan pembentukan kompetensi, serta bertindak sesuai dengan kondisi peserta didik dan lingkungan.

b. Guru Sebagai Pengajar

Guru sebagai pengajar, harus terus mengikuti perkembangan teknologi, sehingga apa yang disampaikan kepada peserta didik merupakan hal-hal yang terbaru dan tidak ketinggalan jaman. Perkembangan teknologi mengubah peran guru dari pengajar yang bertugas menyampaikan materi pembelajaran menjadi fasilitator yang bertugas memberikan kemudahan belajar. uru Sebagai Pembimbing

Sebagai pembimbing, guru harus merumuskan tujuan secara jelas, menetapkan waktu perjalanan, Menetapkan jalan yang harus ditempuh, 
menggunakan petunjuk perjalanan serta menilai kelancarannya sesuai dengan kebutuhan dan kemampuan peserta didik. Sebagai pembimbing semua kegiatan yang dilakukan oleh guru harus berdasarkan kerjasama yang baik antara guru dengan peserta didik. Guru memiliki hak dan tanggungjawab dalam setiap perjalanan yang di rencanakan dan dilaksanakannya.

d. Guru Sebagai Pengarah

Guru adalah seorang pengarah bagi peserta didik, bahkan bagi orang tua. Sebagai pengarah guru harus mampu mendengarkan peserta didik dalam memecahkan permasalahan-permasalahan yang dihadapi, Mengarahkan peserta didik dalam mengambil suatu keputusan dan menemukan jati dirinya. Guru juga dituntut untuk mengarahkan peserta didik dalam mengembangkan potensi dirinya, Sehingga peserta didik dapat membangun karakter yang baik bagi dirinya dalam menghadapi kehidupan nyata di masyarakat.

uru Sebagai Pelatih

Proses pendidikan dan pembelajaran memerlukan latihan keterampilan, baik intelektual maupun motorik, sehingga menuntut guru untuk bertindak sebagai pelatih, yang bertugas melatih peserta didik dalam pembentukan kompetensi dasar sesuai dengan potensi masing-masing peserta didik. Pelatihan yang dilakukan, disamping harus memperhatikan kompetensi dasar juga harus mampu memperhatikan perbedaan individual peserta didik dan lingkungannya. Untuk itu guru harus banyak tahu, meskipun tidak mencakup semua hal dan tidak setiap hal secara sempurna, karena hal itu tidaklah mungkin.

f. Guru Sebagai Penilai

Penilaian atau evaluasi merupakan aspek pembelajaran yang paling kompleks, karena melibatkan banyak latar belakang dan hubungan, serta variabel lain yang mempunyai arti apabila berhubungan dengan konteks yang hampir tidak mungkin dapat dipisahkan dengan setiap segi penilaian. Sebagai suatu proses, penilaian dilaksanakan dengan prinsip-prinsip dan dengan teknik yang sesuai, mungkin tes atau non tes. Mengingat kompleksnya proses penilaian, maka guru perlu memiliki pengetahuan, keterampilan dan sikap yang memadai.

\section{Membaca}

Dalam kamus Besar Bahasa Indonesia (KBBI) kata membaca dapat diartikan melihat serta memahami isi dari apa yang tertulis (dengan melisankan atau hanya dalam hati), mengeja atau melafalkan apa yang tertulis, mengucapkan, mengetahui meramalkan dan memperhitungkan. Membaca merupakan suatu keterampilan berbahasa yang sangat penting peranannya dalam kehidupan. Membaca mempunyai peranan penting dalam melahirkan generasi penerus bangsa yang cerdas, kreatif, dan kritis. Manusia yang berbudaya dan berpendidikan menjadikan membaca menjadi suatu kebutuhan dalam berkomunikasi. Pada dasarnya kemampuan dan keterampilan membaca menjadi suatu kebutuhan yang harus dipenuhi sehingga kemampuan membaca harus dilatih sejak dini. Dengan membaca, peserta didik akan memperoleh pengetahuan yang bermanfaat bagi pertumbuhan dan perkembangan daya fikir dan nalarnya serta perkembangan sosial dan emosional mereka. Oleh karena itu kemampuan pengajaran membaca pada permulaan bertujuan untuk melatih para peserta didik agar terampil dalam membaca lalu menuliskan apa yang mereka pahami. Tarigan (2013:7) menyatakan, membaca adalah suatu proses yang dilakukan serta dipergunakan oleh pembaca untuk memperoleh pesan, yang hendak disampaikan oleh penulis melalui media kata-kata/bahasa tulis. Harjasujana dan Mulyati (dalam Dalman, 2013:6) menyatakan, membaca merupakan perkembangan keterampilan yang bermula dari kata dan berlanjut kepada membaca kritis. 
Dalman (2013:5) menyatakan, membaca adalah suatu kegiatan atau proses kognitif yang berupaya untuk menemukan berbagai informasi yang terdapat dalam tulisan.

Rusyana (dalam Dalman, 2013:6) menyatakan, mengartikan membaca sebagai suatu kegiatan memahami pola-pola bahasa dalam penampilannya secara tertulis untuk memperoleh informasi darinya.

Padaha hakikatnya keterampilan merupakan suatu ilmu yang diberikan kepada manusia, kemampuan manusia dalam mengembangkan keterampilan yang dipunyai memang tidak mudah, perlu mempelajari, perlu menggali agar lebih terampil. Keterampilan merupakan ilmu yang secara lahiriah ada didalam diri manusia dan perlunya dipelajari secara mendalam dengan mengembangkan keterampilan yang dimiliki. Keterampilan dasar sudah pasti harus dimiliki oleh setiap orang adalah membaca, menulis, berhitung, serta mendengarkan.

Keterampilan membaca lebih menitikberatkan kepada kemampuan membaca pemahaman, karena kemampuan memahami bahan bacaan (teks) merupakan tujuan utama yang ingin dicapai dalam pembelajaran membaca. Ruang lingkup membaca di SD meliputi membaca huruf, suku kata, kalimat, paragrap, berbagai teks bacaan, denah, petunjuk, tata tertib, pengumuman, kamus, ensiklopedia serta mengapresiasi dan berekspresi sastra melalui kegiatan membaca hasil sastra berupa dongeng, cerita anak-anak, cerita rakyat, cerita binatang, puisi anak, syair lagu, pantun, dan drama anak. Kompetensi membaca juga diarahkan menumbuhkan budaya membaca.

\section{SIMPULAN}

Guru merupakan kunci sentral untuk keberhasilan suatu pengajaran. Terlebih lagi apabila lingkungan tempat pembelajaran kurang menguntungkan, peran guru sangat berarti bagi siswa karena penentu keberhasilan suatu pengajaran sangat dipengaruhi oleh lingkungan, orang tua dan sekolah.

Berdasarkan beberapa pengertian membaca menurut beberapa ahli di atas dapat disimpulkan bahwa membaca adalah suatu aktifitas membunyikan rangkaian lambang - lambang berupa huruf yang dihubungkan menjadi kata yang memiliki suatu makna tersendiri.

Siswa harus memiliki kemampuan dalam membaca agar dapat memahami makna yang terdapat dalam bacaan. Tanpa adanya kemampuan membaca yang baik, maka siswa tidak akan dapat memahami proses pembelajaran dan materi yang diajarkan. Oleh karena itu, guru sangat berperan dalam meningkatkan kemampuan membaca peserta didik.

\section{DAFTAR PUSTAKA}

Dalman. (2013). Keterampilan Membaca. Jakarta: Rajawali Pers.

Daryanto, dan Herry Sudjendro. (2014). Siap Menyongsong Kurikulum 2013. Yogyakarta: Penerbit Gava Media.

Depdiknas. (2002). Kamus Besar Bahsa Idonesia. Jakarta.

Guntur Tarigan, Henry. (2013). Membaca. Bandung: CV. Angkasa.

Hadiyanto. (2016). Teori dan Pengembangan Iklim kelas dan Iklim Sekolah. Jakarta: Kencana, hlm. 2.

Hakikat Keterampilan. (http://hakikat keterampilan.blogspot.com/)

Rusman. (2010). Model-Model Pembelajaran: Mengembangkan Profesionalisme Guru. Jakarta: Rajawali Press, hIm. 15.

Senogiriyono.( 2011). Upaya Guru Mengembangkan Kemampuan Membaca Tingkat Pemula Dengan Metode Global Pada Peserta didik Kelas 1 MIN Ponjong Gunungkidul, Skripsi, Yogyakarta: UIN Sunan Kalijaga Yogyakarta.

Undang-Undang No. 20 Tahun 2003 tentang Sistem Pendidikan Nasional . Pasal 1. Undang-Undang No. 14 Tahun 2005 tentang Guru dan Dosen, Bab I Pasal 4. 